\title{
Epidemiology of human avian influenza in Indonesia, 2005-2009: a descriptive analysis
}

\author{
Wiku Adisasmito
}

Faculty of Public Health, University of Indonesia, Jakarta, Indonesia

\begin{abstract}
Abstrak
Tujuan Untuk memahami epidemiologi terkait perjalanan natural penyakit, manajemen dan hasil terapi pada kasus Avian influenza (AI) manusia di Indonesia.

Metode Studi observasional ini menggunakan data 93 kasus AI pada manusia yang memiliki konfirmasi laboratorium test terinfeksi H5N1 antara bulan September 2005-Agustus 2009. Kasus diidentifikasi melalui data yang didapat dari Departemen Kesehatan, Dinas Kesehatan Propinsi dan Kabupaten. Data kategori dianalisis dengan distribusi frekuensi, chi-square, relative risks, dan data kontinu dianalisa dengan univariate statistics dan wilcoxon tests.

Hasil Hampir seluruh kasus, 54\%, diterima pertama kali di klinik dan tempat praktek dokter. Semua kasus dirawat RS dan mayoritas, 85\%, dengan gejala gangguan pernafasan pada saat diperiksa. Tidak terlihat adanya hubungan antara karakteristik kasus, yaitu: fasilitas kesehatan pertama yang dikunjungi, dirawatnya kasus di RS, dan gejala klinis yang paling sering muncul,dengan tingkat keselamatan/survival. Kasus yang terpajan langsung dengan unggas memiliki peluang 2,8 kali untuk mendapatkan pengobatan dengan oseltamivir dibandingkan dengan yang tidak terpajan $(R R=2.89,95 \%$ CI 1.44 - 5.78). Jumlah kasus selamat kecil. Kasus-kasus yang menerima pengobatan oseltamivir memiliki peluang $24 \%$ lebih tinggi untuk selamat dari pada yang tidak menerima pengobatan ini (RR $=1.24,95 \%$ CI 0.34-4.58). Kasus yang mendapatkan pengobatan oseltamivir memiliki waktu median dari mulai timbul gejala sampai mendapatkan pengobatan antiviral 2,5 hari di antara kasus yang selamat, dibandingkan dengan 7 hari untuk kasus yang meninggal. Fatalitas dapat berhubungan dengan keterlambatan pemberian antiviral sejak pertama diterima di fasilitas kesehatan.
\end{abstract}

Kesimpulan Pengobatan dini dengan antiviral memiliki kontribusi untuk keselamatan penderita. Namun tingkat kecurigaan yang rendah terhadap penyakit ini akan tetap menjadi faktor penting dalam diagnosa dini. Perlu kebijakan yang terimplementasi secara meluas tentang protokol diagnosa dini dan pengobatan terhadap influenza. (Med J Indones 2010; 19:64-70)

\begin{abstract}
Aim The study set out to better understand the epidemiology, natural history, therapeutic management and outcomes associated with confirmed human cases of Avian Influenza (AI) in Indonesia

Methods This observational study utilized data from 93 cases with laboratory-confirmed H5N1 Influenza between September 2005 and August 2009. Cases were identified through records obtained from the Ministry of Health, as well as the Provincial health office and district health office records. Categorical data were analyzed with frequency tables, chi-square tests, and relative risks, and continuous data were analyzed using univariate statistics and Wilcoxon tests.

Results Most subjects (54\%) first presented to a physician's office or clinic. All of the subjects were hospitalized, and the vast majority $(85 \%)$ had respiratory symptoms as their predominant symptom at presentation. There was no clear association of any of these case characteristics with survival. Cases with direct poultry exposure were 2.8 times more likely to receive oseltamivir treatment than those without direct exposure $(\mathrm{RR}=2.89,95 \% \mathrm{CI} 1.44-5.78)$. While the overall number of survivors was small, cases with documented oseltamivir treatment were approximately $24 \%$ more likely to survive than cases for which oseltamivir treatment was not documented (RR 1.24; 95\% CI: 0.34-4.58). In oseltamivir treated cases, the median time from symptom onset to start of antiviral treatment was 2.5 days in survivors compared to 7.0 days for those who died. Fatality, therefore, may be related to delay in initiation of treatment after presentation.
\end{abstract}

Conclusions The data suggest that early treatment with the antiviral drug oseltamivir may play an important role in survival. However, a low clinical suspicion of disease likely remains an important impediment to early diagnosis. Therefore, a clear policy for the protocol of early diagnosis \& treatment of febrile illness including influenza is necessary. (Med J Indones 2010; 19:64-70)

Key words: human avian influenza, antiviral drugs, oseltamivir, survival, Indonesia 
With the emergence and global spread of influenza H1N1 in 2009, global attention has shifted from avian influenza $\mathrm{H} 5 \mathrm{~N} 1$. Yet H5N1 remains endemic in many countries, notably in Asia, while outbreaks in poultry continue to occur. H5N1 remains a public health challenge. Indeed, some have argued that the risk of a global pandemic with very high mortality rates may be greater given the greater potential for re-assortment of $\mathrm{H} 5 \mathrm{~N} 1$ with $\mathrm{H} 1 \mathrm{~N} 1 .{ }^{1}$ Indonesia remains the country that has reported the greatest number of human cases of $\mathrm{H} 5 \mathrm{~N}^{2}{ }^{2}$.

There have been 442 laboratory-confirmed cases of highly-pathogenic human avian influenza (H5N1) reported to WHO from 15 countries from November 2003 through September 2009. Indonesia reported 32\% of the cases, with a case fatality rate of $81 \%$, compared to $49 \%$ for the other 14 countries.

Given the high rate of human H5N1 cases in Indonesia and the considerably higher case fatality rate compared to other countries, ${ }^{3}$ we undertook an analysis to better understand the natural history, risk factors, therapeutic management, and outcomes associated with confirmed cases of human avian influenza in Indonesia. It is hoped that a better understanding of these factors will lead to: better disease prevention, management and outcomes, and better evidence for health system policy formulation.

\section{METHODS}

Data on confirmed human avian influenza (H5N1) cases reported to the Indonesian Ministry of Health for the period $1^{\text {st }}$ Jan 2005 to $31^{\text {st }}$ May 2009 were collected from 3 provinces that documented the greatest number of H5N1 cases: Jakarta, Banten, and West Java. All cases had laboratory confirmation of human H5N1 influenza, and met the Ministry of Health case definition, which included the presence of a fever greater than 38 degrees Celsius, plus one of the following symptoms: cough, sore throat, headache, myalgia, conjunctivitis, dyspnoea, diarrhoea, GI tract disorder, and malaise. Laboratory confirmation consisted of one of the following: isolation of influenza A H5N1 virus; influenza A H5N1 detected by PCR; increase neutralizing antibody titer of $\mathrm{H} 5 \mathrm{~N} 1$ and convalescent specimen compared to acute specimen, and convalescent titer neutralizing antibody titer of $1 / 80$ or greater; or neutralizing antibody titer of $\mathrm{H} 5 \mathrm{~N} 1$ of $1 / 80$ or more on serum specimen on day 14 or later after onset. ${ }^{4}$

This observational study ${ }^{5}$ used data which were collected sequentially, starting with cases reported to provincial and district health offices. Data were abstracted from the Epidemiology Investigation Reports (EIR) ${ }^{6}$ obtained from provincial and district offices onto a structured data collection sheet. Data sheets that were used to inform the EIRs were also reviewed. Data included name, sex, date of birth, address, educational attainment, contact history with poultry and persons, course and chronology of diseaserelated events including fever, pulse, respiratory rate, laboratory tests including hemoglobin, platelets, leucocytes, haematocrit, SGOT, SGPT), presence of pneumonia, signs and symptoms (cough, fever, dyspnoea, sore throat, headache, malaise, level of consciousness, vomiting), date of diagnosis, treatment dates and doses (antivirals, antibiotics, antipyretics, expectorants, analgesics), hospital admission and discharge dates, information on referral to hospitals, ventilator requirements, ${ }^{7}$ and either copies of X-rays or $\mathrm{X}$-ray reports. ${ }^{8}$ Other data collected included data on risk factors (people whom the case had contacted, number and nature of contacts with poultry in preceding week, condition of the poultry with which there was contact, distance from poultry market, and distance from dead poultry). Maps of residential areas and distances to identified risk factors were plotted where known.

Data abstracted from the EIRs was verified, and additional data was retrieved, from medical records obtained from the health facilities. Data on progress was recorded including clinical status, progress, treatment, and results of investigations. The Ministry of Health Epidemiology Investigation Report (EIR) data sheets were informally reviewed to verify data from province and district offices. All data collected were entered into structured data collection forms.

In summary, data were retrieved and verified from 4 sources: 1) District and provincial EIR; 2) primary data collection sheets at district and province offices; 3) clinical records; 4) Ministry of Health EIR. When discrepancies in data collected from different sources existed, the data identified from the clinical medical record was used as the most reliable source data. Treatment with oseltamivir was documented if noted in any recorded source. However, since clinical record data were not always available or complete, treatment was analyzed as "documented" or "not documented" since treatment may have been provided but not documented in the available data sources. The analysis is descriptive. Categorical data were analyzed with frequency tables, chi-square tests, and relative risks, and continuous data were analyzed using univariate statistics and Wilcoxon tests. ${ }^{9}$ 


\section{RESULTS}

There were only 93 laboratory confirmed cases of human $\mathrm{H} 5 \mathrm{~N} 1$ avian influenza from 3 provinces in Indonesia between September 2005 and August 2009 were analyzed. Case characteristics are presented in Table 1. The median age at onset was 18 years (range 1 to 67 years), and $51 \%$ of cases were female. The majority $(54 \%)$ of patients first presented to a physician's office or clinic for medical care, and the predominant symptom at presentation was respiratory (85\%). All patients were hospitalized. The only antiviral documented as treatment in this population was oseltamivir, and 25 subjects $(27 \%)$ were documented as having been treated with oseltamivir. The overall case fatality rate was $89 \%$. Cause of death was reported as pneumonia in 42 subjects (44\%) and acute respiratory distress syndrome (ARDS) or progressive respiratory failure in 21 subjects $(22 \%)$.
Of the 85 subjects for whom exposures were documented, the most common exposure was having been in the vicinity of live poultry, such as visiting a live poultry market $(36 \%)$ (Table 1). The second most common route of exposure was to poultry confirmed or suspected as having been infected with avian influenza (30\%), including slaughtering, handling excrement, consuming, or having other direct contact with such poultry, or having poultry deaths in the home. Only 5 subjects $(5 \%)$ reported having been exposed to a human case of AI, with three having had some form of exposure to poultry. Having direct poultry exposure appeared to increase the likelihood of a case being treated with oseltamivir (Table 2 ). Cases with direct poultry exposure were nearly 3 times more likely to have had documented oseltamivir treatment than cases without direct poultry exposure (RR 2.89; 95\% CI: 1.44-5.78).

Table 1. Characteristics of human H5N1 avian influenza cases in Indonesia, 2005-2009.

\begin{tabular}{lr}
\hline Case Characteristics & $\begin{array}{c}\text { Total Sample } \\
(\mathrm{n}=93)\end{array}$ \\
\hline Age (y), median (range) & $18(1-67)$ \\
Female & $51(55 \%)$ \\
Facility first presented for medical attention* & \\
$\quad$ Emergency Room & $19(20 \%)$ \\
Physician's office/clinic & $50(54 \%)$ \\
Rural Health Service & $2(2 \%)$ \\
Other & $21(22 \%)$ \\
Predominant Symptom at Presentation* & \\
Respiratory & $78(85 \%)$ \\
Gastrointestinal & $11(12 \%)$ \\
Neurological & $1(1 \%)$ \\
Fever only & $2(2 \%)$ \\
Hospitalized & $93(100 \%)$ \\
Documented Antiviral treatment received & $25(27 \%)$ \\
Died & $83(89 \%)$ \\
Exposure & \\
Direct exposure to AI poultry (no human contact) & $28(30 \%)$ \\
Indirect exposure to AI poultry (no human contact) & $14(15 \%)$ \\
In vicinity of live poultry (no human contact) & $34(37 \%)$ \\
Human contact only & $2(2 \%)$ \\
Human and poultry exposure & $3(3 \%)$ \\
Exposure not known & $7(8 \%)$ \\
Other exposure & \\
$\quad$ Deny exposure & $2(2 \%)$ \\
$\quad$ Other: bought and cooked poultry & $1(1 \%)$ \\
$\quad$ Any wild bird & $2(2 \%)$ \\
\hline
\end{tabular}

* data available for 92 subjects 
Table 2. Association of documented oseltamivir treatment with direct poultry exposure for cases of human H5N1 avian influenza in Indonesia, 2005-2009

\begin{tabular}{|c|c|c|c|c|c|}
\hline \multirow[b]{2}{*}{ Oseltamivir treatment* } & \multicolumn{2}{|c|}{ Survived } & \multirow[b]{2}{*}{ Total } & \multirow[b]{2}{*}{$\mathrm{RR}$} & \multirow[b]{2}{*}{$95 \% \mathrm{CI}$} \\
\hline & $\overline{\text { Yes }}$ & No & & & \\
\hline Yes, n (\%) & $3(12.0)$ & $22(88.0)$ & 25 & 1.24 & $0.34-4.58$ \\
\hline Not documented, n (\%) & $6(9.7)$ & $56(90.3)$ & 62 & & \\
\hline Total & 9 & 78 & 87 & & \\
\hline
\end{tabular}

RR: Relative Risk

CI: Confidence Interval

*Notes: treatment were not available for 6 subjects

Cases with documented oseltamivir treatment were approximately $24 \%$ more likely to survive than cases for which oseltamivir treatment was not documented (RR 1.24; 95\% CI: 0.34-4.58) (Table 3). Additional information regarding timing of documented oseltamivir treatment and survival is presented in table 4 . For the 25 cases that were reported to have been treated with oseltamivir, the median time from symptom onset to presentation for medical care was similar in both treated cases who survived and those who died, and most often occurred within one day after onset of symptoms. In contrast, the median time from presentation to initiation of treatment, was shorter in survivors (2.5 days) compared to those who died (5 days). The time from symptom onset to start of antiviral treatment was shorter in those who survived (2.5 days) compared to those who died (7.0 days). Interpretation of the median times presented for treated survivors must be made with caution, given that there were only three surviving treated cases, and of those, treatment start date was only available for 2 cases. Case fatality rate by time from symptom onset to the start of oseltamivir treatment is presented in Figure 1. Both treated survivors received oseltamivir within five days from symptom onset, whereas all 14 subjects treated after day six died.

Table 3. Documented oseltamivir treatment and survival for cases of human H5N1 influenza infections in Indonesia, $2005-2009$.

\begin{tabular}{|c|c|c|c|c|c|}
\hline \multirow[b]{2}{*}{ Direct Poultry Exposure } & \multicolumn{2}{|c|}{ Oseltamivir treatment } & \multirow[b]{2}{*}{ Total } & \multirow[b]{2}{*}{$\mathrm{RR}$} & \multirow[b]{2}{*}{$95 \% \mathrm{CI}$} \\
\hline & Yes & Not documented & & & \\
\hline Yes, n (\%) & $15(50)$ & $15(50)$ & 30 & 2.89 & $1.44-5.78$ \\
\hline No, n (\%) & $9(17)$ & $43(83)$ & 52 & & \\
\hline Total & 24 & 58 & 82 & & \\
\hline
\end{tabular}

RR: Relative Risk

CI: Confidence Interval 
Table 4. Timing of treatment and survival: Cases of human H5N1 influenza in Indonesia, 2005-2009.

\begin{tabular}{|c|c|c|}
\hline \multirow[t]{2}{*}{$\begin{array}{l}\text { Timing from symptom onset to presentation for } \\
\text { treatment (days) }\end{array}$} & \multicolumn{2}{|c|}{$\begin{array}{l}\text { Treated with Oseltamivir Noted } \\
\qquad(\mathrm{n}=25)\end{array}$} \\
\hline & $\begin{array}{c}\text { Survived } \\
\text { Median (Range) } \\
\text { (n) } \\
\end{array}$ & $\begin{array}{c}\text { Died } \\
\text { Median (Range) } \\
\text { (n) } \\
\end{array}$ \\
\hline Symptom onset to presentation for medical care & $\begin{array}{c}0(0-0) \\
(\mathrm{n}=3)\end{array}$ & $\begin{array}{l}1(0-7) \\
(\mathrm{n}=22)\end{array}$ \\
\hline Presentation to start of oseltamivir treatment & $\begin{array}{l}2.5(2-3) \\
\quad(n=2)\end{array}$ & $\begin{array}{c}5(1-11) \\
(\mathrm{n}=20)\end{array}$ \\
\hline Symptom onset to start of oseltamivir treatment & $\begin{array}{c}2.5(2-3) \\
(\mathrm{n}=2)\end{array}$ & $\begin{array}{l}7(1-12) \\
(\mathrm{n}=20)\end{array}$ \\
\hline Duration of oseltamivir treatment & $\begin{array}{l}1.5(1-2) \\
(\mathrm{n}=2)\end{array}$ & $\begin{array}{l}3(1-6) \\
(n=17)\end{array}$ \\
\hline
\end{tabular}

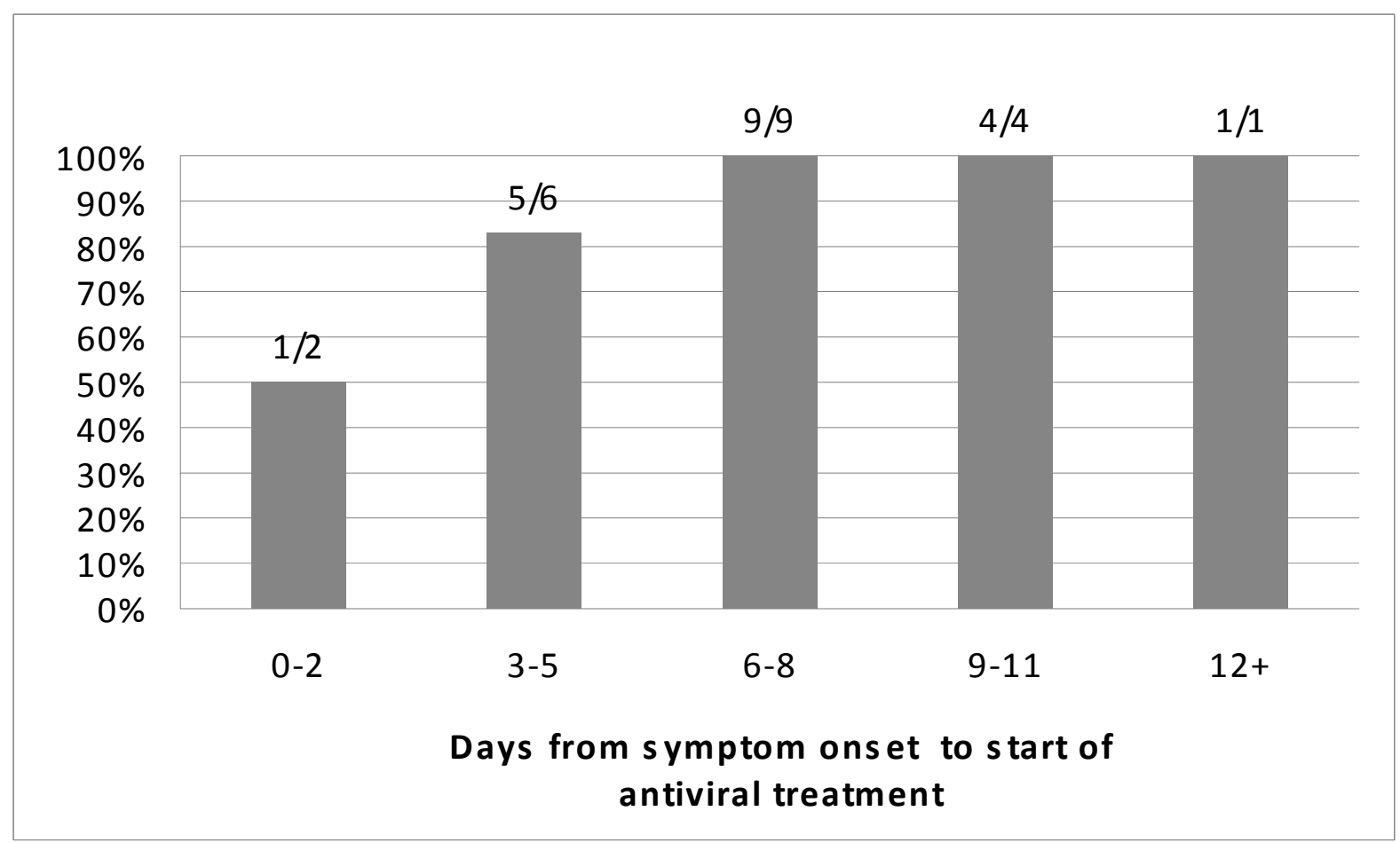

Figure 1. Case fatality rate from time at symptom onset to start of oseltamivir treatment: Human H5N1 influenza in Indonesia, 2005-2009. 


\section{DISCUSSION}

The human disease resulting from $\mathrm{H} 5 \mathrm{~N} 1$ is associated with very high mortality rates in Indonesia. More than half of cases present with respiratory symptoms but a significant minority had gastrointestinal symptoms and a small minority present with only fever, similar to other reported case series. ${ }^{10,11}$ Patients present first to a number of clinical settings, most usually a physician's office but also emergency rooms and rural health centers. Whilst poultry exposure was not, in our analysis, a predictor of survival, it was associated with treatment with oseltamivir suggesting that a higher index of clinical suspicion for H5N1 occurs in clinicians when the patients report contact with poultry. This concurs with the reports suggesting better clinical outcomes in patients that are part of clusters of cases where clinical suspicion is likely to be high. ${ }^{12}$ Whilst survival was not statistically significantly associated with treatment with oseltamivir, delays in the initiation of treatment occurred in many cases. Early treatment was associated with increased survival, but importantly early presentation for clinical care was not because of delays in initiating treatment with oseltamivir. Thus, the implication is that early treatment is important in achieving clinical success and a high index of clinical suspicion is necessary for patients presenting, sometimes with non-specific symptoms, to clinical settings. Where the incidence of disease is low, this remains a profound challenge. Whilst, awareness by clinicians of disease in the animal health sector might raise clinical suspicion in cases associated with poultry most clearly, ${ }^{11}$ the awareness also has the potential to lower clinical suspicion in cases not reporting contact with poultry. These findings concur broadly with the clinical research from other case series reported recently, ${ }^{11-14}$ and offer further evidence building notably on the case series of Kandun et al. reported from Indonesia through an extension of the cases previously reported to include more recent cases from three provinces in Indonesia. ${ }^{11}$

There are some limitations to this study. The sample size was small and few patients received treatment, and even fewer received early treatment restricting the ability to uncover significant variables. We did not collect data on the clustering of cases or determine quantitatively severity of disease at presentation, both of which among other variables may confound results.

Human AI in Indonesia is a highly lethal infection, with a high case fatality rate. ${ }^{3}$ In cases unable to access antiviral treatment the case fatality rate appears to be more than $90 \%$. Though the number of survivors in this study was small, these data suggest that early treatment with oseltamivir may yet have substantial benefit in terms of survival. For these benefits to accrue, clinical suspicion needs to be raised among physicians and other care-givers as the disease is likely to remain a profound challenge when the incidence is low and in a country with many other pressing public health problems. A clear policy for the protocol of early diagnosis $\&$ treatment of febrile illness including influenza is clearly necessary.

\section{Acknowledgment}

This high appreciation should go to the collaborators of this research. Nancy Dreyer, Robin Seitzman \& Anna Layton of Outcome Sciences Inc. Cambridge, MA USA, who have provided the data analysis. Prof Richard Coker, London School of Hygiene \& Tropical Medicine, London, UK who supported the systematic data collection and analysis of the data. Stephen Toovey, Royal Free and University College Medical School, London, UK who participated in giving input to analysis. The last but not the least who deserves the most appreciated work is Kamaluddin Latief, Faculty of Public Health, University of Indonesia, Depok, Indonesia. His dedication with the field research team in the systematic field data collection is valuable to this research. This research became possible with the support from London School of Hygiene and Tropical Medicine and F. Hoffmann-La Roche.

\section{REFERENCES}

1. Fedson DS. Preparing for pandemic vaccination: an international policy agenda for vaccine development. J Public Health Policy, 2005. 26(1): p. 4-29.

2. WHO. Cumulative Numbers of Confirmed Human Cases of AI A/ (H5N1) Reported to WHO. 2009 [cited in 2009 Des 14]. Available from: URL: http://www.who.int/csr/ disease/avian_influenza/country/cases_table_2009_12_11/ en/index.html

3. WHO. Western Pacific Regional Office of the World Health Organization: Avian Influenza Update Number 193 (April 22, 2009). 2009 [cited in 2009 Des 14]. Available from: URL: http://www.wpro.who.int/NR/ rdonlyres/4B77E135-F15A-471D-9267-9B2F2EC04F6D/0/ AIWeekly193WPRO22April2009.pdf; p.2

4. Depkes RI. Pedoman Pengambilan dan Pengiriman Spesimen yang Berhubungan Dengan Flu Burung. Jakarta: Puslitbang Biomedis dan Farmasi Litbangkes Depkes RI; 2006

5. Gerstman BB. Epidemiology Kept Simple: An Introduction to Traditional and Modern Epidemiology. $2^{\text {nd }}$ Ed. New Jersey: Wiley-Liss, Inc; 2003; p.192 
6. Depkes RI. Modul Pelatihan Tim Gerak Cepat Pengendalian Flu Burung dan Kesiapsiagaan Menghadapi Pandemi Influenza. Modul 4; lampiran. Jakarta: Depkes RI; 2007

7. The Writing Committee of the World Health Organization (WHO) Consultation on Human Influenza A/H5. Avian Influenza A (H5N1) Infection in Humans. New Eng J Med, 2006. 353 (13): p. 1374-85

8. Yamada S, Suzuki Y, Suzuki T, Le MQ, Nidom CA, SakaiTagawa Y, et. al. Haemagglutinin mutations responsible for the binding of H5N1 influenza A viruses to humantypereceptor. Nature, 2006 [cited in 2009 Des 14]. 444: p. 378-82. Available from: URL: http://www.nature.com/ nature/journal/v444/n7117/abs/nature05264.html

9. Selvin S. Statistical Analysis of Epidemiologic Data. New York: Oxford University Press; 1991. p. 75; 305-9.

10. Hien TT, Liem NT, Dung NT, San LT, Mai PP, Chau NvV, et al. Avian influenza A (H5N1) in 10 patients in Vietnam. N Engl J Med, 2004. 350(12): p. 1179-88.

11. Kandun IN, Tresnaningsih E, Purba WH, Lee V, Samaan G, Harun S, et al. Factors associated with case fatality of human H5N1 virus infections in Indonesia: a case series. Lancet, 2008. 372(9640): p. 744-9.
12. Kandun IN, Wibisono H, Sedyaningsih ER, Yusharmen, Hadisoedarsuno W, Purba W, et al. Three Indonesian clusters of H5N1 virus infection in 2005. N Engl J Med, 2006. 355(21): p. 2186-94.

13. Thorson A, Petzold M, Nguyen TK, Ekdahl K. Is exposure to sick or dead poultry associated with flulike illness?: a population-based study from a rural area in Vietnam with outbreaks of highly pathogenic avian influenza. Arch Intern Med, 2006. 166(1): p. 119-23.

14. Oner AF, Bay A, Arslan S, Akdeniz H, Sahin HA, Cesur Y, et al. Avian influenza A (H5N1) infection in eastern Turkey in 2006. N Engl J Med, 2006. 355(21): p. 2179-85.

15. Bridges CB, Katz JM, Seto WH, Chan PK, Tsang D, Ho $\mathrm{W}$, et al. Risk of Influenza A (H5N1) Infection among Health Care Workers Exposed to Patients with Influenza A (H5N1), Hong Kong. The Journal of Infectious Diseases, 2000 [cited in 2009 Des 14]. 181:344-8. Available from: URL: http://www.journals.uchicago.edu/doi/ full/10.1086/315213? cookieSet $=1$ 